\title{
Effects of Frontal Recess Cells on the Development of Frontal Sinusitis
}

\author{
Joo Hwan Jung, Bong-Joon Jin, Jin Hyeok Jeong, \\ Seok Hyun Cho, Seung Hwan Lee and Kyung Rae Kim \\ Department of Otolaryngology, College of Medicine, Hanyang University, Seoul, Korea
}

\author{
전두동 개구부 봉소가 전두동염의 발생에 미치는 영향 \\ 정주환 · 진봉준 · 정진혁 · 조석현 · 이승환 · 김경래 \\ 한양대학교 의과대학 이비인후과학교실
}

Received August 18, 2012

Revised October 17, 2012

Accepted October 25, 2012

Address for correspondence

Kyung Rae Kim, MD

Department of Otolaryngology,

College of Medicine,

Hanyang University,

222 Wangsimni-ro, Seongdong-gu,

Seoul 133-792, Korea

Tel $+82-2-2293-8587$

Fax $+82-2-2293-3335$

E-mail krkim@hanyang.ac.kr
Background and Objectives Frontal recess anatomy can be very complex, with accessory cells extending to the frontal sinus and possibly contributing to the obstruction of the frontal sinus. However, there is still controversy on the effect of the frontal recess cells. We designed this study to assess the effect of frontal recess cells on frontal sinusitis.

Subjects and Method We retrospectively reviewed chart and collected data of those who visited the outpatient clinic between January and June, 2011. Parnasal sinus CT was taken with Brillance 64-slice computed tomography scanners. The image was reviewed by two or more otolaryngologists to identify the frontal recess cells. The nasofrontal isthmus diameter and the area of nasofrontal isthmus was reconstructed and measured with workstation. Then, we compared the radiological results of frontal recess cells with the frequency of frontal sinusitis.

Results The presence of anterior group of frontal recess cells showed no influence on the frontal recess anatomy. The presence of frontal bullar cell was significantly associated with the development of frontal sinusitis by simple $(p=0.001)$ and multiple $(p=0.038)$ logistic regression models. It was shown that the narrower the area of frontal isthmus the more developed were the frontal sinusitis, showing statistically significance in the simple $(p=0.013)$ and multiple $(p=$ 0.017) logistic regression models.

Conclusion Our results also showed that similar results compared to previous Asianreport. The narrowness of nasofrontal isthmus could be the cause of frontal sinusitis. The frontal bullar cell could be the cause of frontal sinusitis encroaching on the frontal recess and affect the nasofrontal pathway.

Korean J Otorhinolaryngol-Head Neck Surg 2012;55:693-700

Key Words Frontal recess cells $\cdot$ Frontal sinusitis $\cdot$ Koreans.

\section{서 론}

약 25년 전부터 내시경적 부비동 수술을 시행하기 시작하였 으며, 현재 내과적 치료에 반응하지 않는 부비동염에서 기본치 료로 시행되고 있다. 전두동염의 내시경적 수술에 있어 전두동 개구부의 해부학적 구조에 대한 포괄적인 이해는 합병증의 예 방 및 성공적인 치료 효과를 위해 필수적이다. 전두동 개구부 의 해부는 변이가 심할 뿐 아니라 내측으로는 후각신경(olfac- tory nerve), 가측으로는 지판, 후방으로는 사골포(bulla ethmoidalis), 전사골동맥(anterior ethmoid artery) 등이 얇은 뼈로 둘러싸여 구성을 이루고 있다.

전두동 개구부란 전두동 배출구에 존재하는 모래시계 모양 의 복잡한 공간이다. 이 공간은 비제봉소(agger nasi cell), 제 1형, 제2형, 제3형, 제4형 전두봉소(frontal cell)로 이루어진 전 방군, 전두사골포봉소(frontal bullar cell), 상사골포봉소(suprabullar cell), 상안와봉소(supraorbital ethmoid cell)로 이 
루어진 후방군, 동간중격봉소(intersinus septal cell)의 중앙 군으로 분류되는 전두동 개구부 봉소(frontal recess cell) 등 으로 이루어지며 전두동은 전두동 개구부 봉소에 의해 함기 화될 수 있다. 특히 전두봉소와 동간중격봉소의 유무나 구상 돌기의 부착부위, 비제봉소나 상안와봉소 등의 해부학적인 구 조물들에 의해 전두동 개구부로의 접근이 어려울 뿐만 아니라 이들에 의해 전두동 개구부 유출로가 좁아진다.1) 전두동 개구 부는 공간이 협소하고, 주위에 전사골동맥, 두개기저부, 지판 등 이 있어 수술적 조작이 힘들고 위험하여 병변의 완벽한 제거 가 어려우며 술 후 협착이 발생할 수 있어 전두동 내시경수술 을 하는 도중 전두동의 적절한 배출과 환기를 위해 전두동 개 구부 봉소의 완전한 제거가 필요하다.2)

최근 20년간 내시경과 컴퓨터단층촬영 장비의 발전으로 인 해 전두동 개구부 주변 구조에 대한 이해의 폭은 넓어졌다. 전 두동 개구부 봉소를 정확히 파악하기 위해서는 좁은 간격으 로 영상이 촬영되어야 하며, 축상면(axial), 관상면(coronal), 시 상면(sagittal)을 모두 활용하여 전두동 개구부 봉소들을 입체 적으로 판단하여야 한다.

이러한 해부학적 구조물들이 전두동 유출로의 폐쇄를 일으 킬 수 있는 요소이기는 하지만 전두동염과의 연관성을 규명하 기 위해 한국인을 대상으로 한 연구는 많지 않을 뿐만 아니라, 전두봉소와 비제봉소의 전두동염과의 관련성에 대해서는 서 로 상반된 결과를 나타내고 있는 실정이다. ${ }^{3-5)}$

이에 저자들은 기존의 연구들이 대개 $1.25 \mathrm{~mm}$ 이상의 간 격으로 촬영한 것보다 좁은 $0.75 \mathrm{~mm}$ 간격으로 촬영한 부비동 전산화단층촬영 영상으로 한국인에 있어 전두동 개구부 봉소 의 발현 빈도와 전두동염에 미치는 영향에 대하여 연구해보고 자 하였다.

\section{대상 및 방법}

2011년 1월부터 2011년 6월까지 한양대학교병원 이비인후과 외래를 방문하여 부비동 전산화단층촬영을 시행한 모든 환자 169 명을 대상으로 하였다. 18세 미만의 소아, 외국인, 비강 혹 은 부비동의 종양 환자, 광범위한 비용종으로 해부학적 유출 로가 막혀있는 경우, 부비동 수술이나 외상의 기왕력이 있는 경 우, 전두동의 선천성 미발달이 있는 환자를 차트 및 촬영영상 을 참고하여 제외하였다. 64 명을 제외 후 연구 대상자는 105 명 이었으며, 총 210 측 부비동 중 일측 부비동이 미발달한 9 명의 일측 부비동을 제외한 201측의 부비동을 대상으로 하였다. 이 들의 평균나이는 40.1( \pm 15.9$)$ 세였고, 남자 66명, 여자 39명이 었다.

105 명의 환자는 축상면 부비동 전산화단층촬영을 시행하
였다. 전산화단층촬영은 Brilliance 64-slice CT scanners(Philips Medical Systems, Haifa, Israel)를 이용하여 $0.75 \mathrm{~mm}$ 두께로 축상면을 측정하였으며, 관상면과 시상면은 Wizard CT workstation(Simens Healthcare, Forchheim, Germany)을 통해 $1 \mathrm{~mm}$ 두께로 재구성되었다.

전두동 개구부 봉소는 널리 보편화된 Lee 등이 비ㄹㅏㅛ한 기 준에 맞춰 분류하였으며(Table 1), 비제봉소와 제1형 전두봉소 (Fig. 1), 제2형 전두봉소(Fig. 2), 제3형 전두봉소(Fig. 3), 상 안와봉소(Fig. 4), 전두사골포봉소(Fig. 5), 상사골포봉소(Fig. 6), 동간중격봉소(Fig. 7) 등을 발견하였다. 모든 전두동 개구 부 봉소는 축상면, 시상면, 관상면 등을 종류에 따라 종합적으 로 관찰하여 분류하였다. 또한 관상면에서 구상돌기의 부착부 위를 따라 말단와(Recessus terminalis)를 관찰하였다(Fig. 7). 전두동 개구부 봉소의 분류는 저자의 이비인후과 전문의 들이 참여하였으며, 애매한 경우 2 명 이상이 동의하였을 때를 기준으로 분류하였다.

전두동 배출로의 최소거리(nasofrontal isthmus diameter) 및 단면적(area of nasofrontal diameter)은 DelGaudio 등기 이 연구한 논문을 참고하여 측정하였다. 전두동 배출로의 최소거 리는 시상면에서 관찰할 수 있는 가장 뒤쪽으로 돌출된 전두 동 부리(frontal beak)에서 전두동의 후벽 혹은 전방 전사골 동 천장까지의 거리로 측정하였다(Fig. 8). 전두동 배출로의 단 면적은 최소거리와 일치하는 선을 따라 Rapidia version 2.8 (Infinitt Technology, Seoul, Korea)을 이용하여 축상면에서 보다 경사지게 재구성하여 해당 프로그램을 이용하여 측정하 였다(Fig. 9).

전두동염의 정의는 이전의 연구를 참조하여 임상적 정의를 배제 후 방사선학적으로 전산화단층촬영에서 전두동의 전체 혹은 $50 \%$ 가 넘는 부분에서 점막비후가 $3 \mathrm{~mm}$ 이상일 경우 전 두동염이 있는 것으로 간주하였다. ${ }^{2,7)}$

통계분석은 Statistical Package for Social Science(SPSS, version 17.0, SPSS Inc., Chicago, IL, USA)를 이용하였으며 전두동 개구부 봉소의 유무에 관한 전두동염에 대해 일변량, 다변량 logistic 회귀분석을 사용하였다. 통계학적 유의 수준 은 $95 \%$ 이상 $(p$-value< $<.05)$ 으로 하였다.

\section{결 과}

전방군 중 비제봉소는 $91.5 \%$ (184측)에서 발견되었다. 전두 봉소 1형은 31.8\%(64측), 2형은 13.9\%(28측), 3형은 8.0\%(16측) 에서 발견되었으며 4형은 발견되지 않았다. 이들 봉소의 확인 을 위해서 관상면과 시상면을 동시에 비교관찰하여 판독하였 다. 후방군 중 상안와봉소는 $12.4 \%$ (25측)에서 발견되었으며 축 
Table 1. Frontal pneumatization pattern definitions and criteria

\begin{tabular}{|c|c|}
\hline Frontal recess cell & Description \\
\hline Aggernasi cell & $\begin{array}{l}\text { - "The most anterior ethmoid cell" } \\
\text { - Swelling along lateral nasal wall anterior to middle turbinate vertical attachment (endoscopic view) } \\
\text { - Pneumatization of the aggernasi region } \\
\text { - Well seen on sagittal and coronal CT images }\end{array}$ \\
\hline Frontal cell, type 1 & $\begin{array}{l}\text { - Single anterior ethmoid cell above the aggernasi cell } \\
\text { - Posterior wall is not skull base; posterior wall is free partition in the frontal recess } \\
\text { - Well seen on coronal and sagittal CT images }\end{array}$ \\
\hline Frontal cell, type 2 & $\begin{array}{l}\text { - Tier of } 2 \text { or more anterior ethmoid cells that pneumatize above the aggernasi cell } \\
\text { - Posterior wall is not skull base; posterior wall is free partition in the frontal recess } \\
\text { - Well seen on coronal and sagittal CT images }\end{array}$ \\
\hline Frontal cell, type 3 & $\begin{array}{l}\text { - Single large anterior ethmoid cell above the aggernasi cell } \\
\text { - Pneumatizes along inner aspect of the anterior frontal sinus table from the anterior frontal recess } \\
\text { - Extends far into true frontal sinus; superior wall (cap) inserts upon inner aspect of the frontal sinus } \\
\text { table (seen on sagittal CT images) } \\
\text { - Posterior wall is not skull base; posterior wall is free partition in the frontal recess } \\
\text { - Well seen on coronal and sagittal CT images }\end{array}$ \\
\hline Frontal cell, type 4 & $\begin{array}{l}\text { - Apparently isolated cell within frontal sinus and above the aggernasi cell } \\
\text { - Appears as an "air bubble" on coronal CT scan } \\
\text { - Appears as a "balloon on a string" on sagittal CT scan } \\
\text { - The anterior/inferior margin is anterior frontal sinus table or frontal sinus floor } \\
\text { - The posterior boundary is cell wall, not posterior frontal sinus table } \\
\text { - Identification requires both sagittal and coronal CT }\end{array}$ \\
\hline $\begin{array}{l}\text { Supraorbital ethmoid } \\
\text { cell }\end{array}$ & $\begin{array}{l}\text { - Ethmoid cell that extends over the orbit from the frontal recess } \\
\text { - May be single or multiple } \\
\text { - May mimic the appearance of a septate frontal sinus } \\
\text { - Opens into the lateral aspect of the frontal recess (this opening is lateral and posterior to the true } \\
\text { frontal sinus ostium) } \\
\text { - Identification requires review of both axial and coronal CT images }\end{array}$ \\
\hline Frontal bullar cell & $\begin{array}{l}\text { - Ethmoid cell above ethmoid bulla } \\
\text { - Pneumatizes along skull base into frontal sinus posterior frontal recess } \\
\text { - Posterior wall is anterior cranial fossa skull base (frontal sinus posterior table) } \\
\text { - Anterior border must extend into frontal sinus } \\
\text { - Located behind true frontal sinus pneumatization tract } \\
\text { - May represent pneumatization of the anterior wall of the ethmoidal bulla (bulla lamella) } \\
\text { - May cause convexity in floor of frontal sinus } \\
\text { - Well seen on sagittal CT }\end{array}$ \\
\hline Suprabullar cell & $\begin{array}{l}\text { - Ethmoid cell above ethmoid bulla } \\
\text { - Superior wall is anterior cranial fossa skull base } \\
\text { - Anterior border does not extend into frontal sinus } \\
\text { - May represent pneumatization of the anterior wall of the ethmoid bulla (bulla lamella) } \\
\text { - Well seen on sagittal CT } \\
\text { - Bears close resemblance to the suprabullar recess (CT alone is inadequate to distinguish between } \\
\text { the SBC and the suprabullar recess) }\end{array}$ \\
\hline $\begin{array}{l}\text { Interfrontal sinus septal } \\
\text { cell }\end{array}$ & $\begin{array}{l}\text { - Pneumatization of the frontal sinus septum } \\
\text { - Drains into one frontal recess } \\
\text { - Associated with pneumatized crista galla } \\
\text { - Well seen on axial and coronal sinus CT }\end{array}$ \\
\hline Recessusterminalis & $\begin{array}{l}\text { - The superior uncinate process attaches laterally to the orbit, below internal frontal ostium } \\
\text { - Frontal sinus drains directly into middle meatus } \\
\text { - Often associated with aggernasi cell } \\
\text { - Well seen on coronal sinus CT }\end{array}$ \\
\hline
\end{tabular}
Adopted from 3D computed tomographic analysis of frontal recess anatomy in patients without frontal sinusitis, Otolaryngol Head Neck Surg 2004;131(3):164-73. SBC: suprabullar cell

상면에서는 전두사골포봉소 혹은 관상면에서는 전두동 격막 을 상안와봉소로 오인하는 경우가 많았으며 확인을 위해서 관 상면과 축상면을 동시에 비교관찰하였다. 전두사골포봉소는 18.9\%(38측)에서, 상사골포봉소는 33.3\%(67측)에서 발견되었 다. 중앙군인 동간중격봉소는 $8.5 \%(17$ 명)에서 발견되어 각각
좌, 우측 부비동으로 배출관이 연결되었다. 말단와는 36.3\%(73 측)에서 발견되었다(Table 2).

총 105 명의 환자 201측의 부비동을 대상으로 부비동 전산 화단층촬영을 시행한 결과 31 측에서 영상학적으로 전두동 염으로 진단되었다. 
Fig. 1. The agger nasi cell (1) and the type 1 frontal cell (2) is seen on coronal and sagittal CT images. The type 1 frontal cell occurs above the agger nasi cell as seen in the coronal and sagittal CT images.
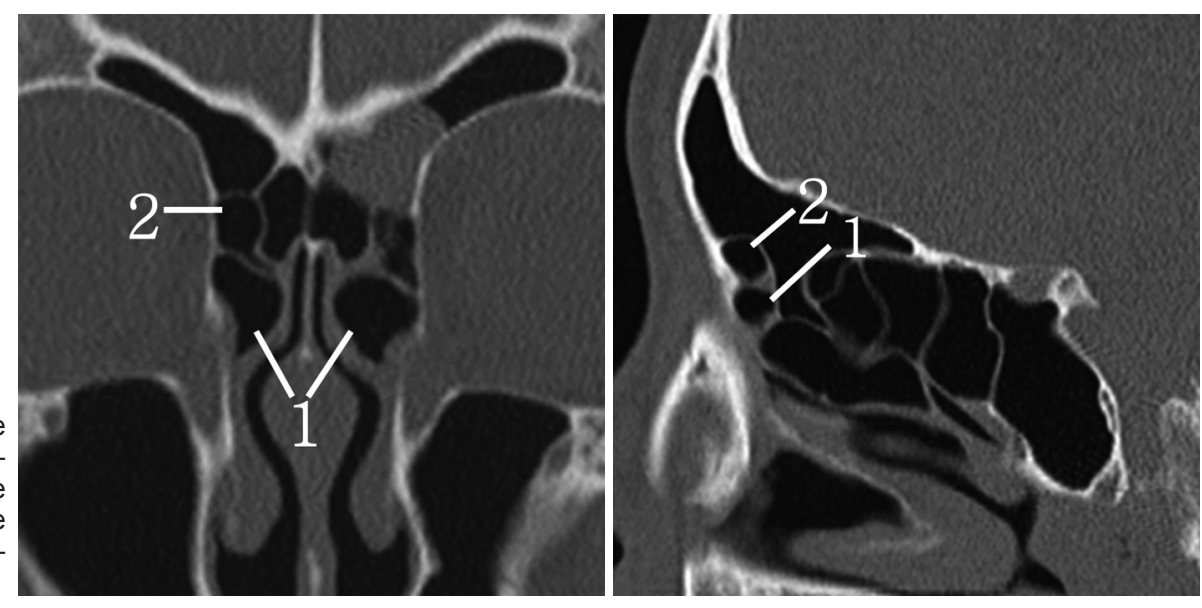

Fig. 2. The type II frontal cell (2) is tier of 2 or more anterior ethmoid cells as shown above the agger nasi cell (1) in this coronal paranasal sinus image.
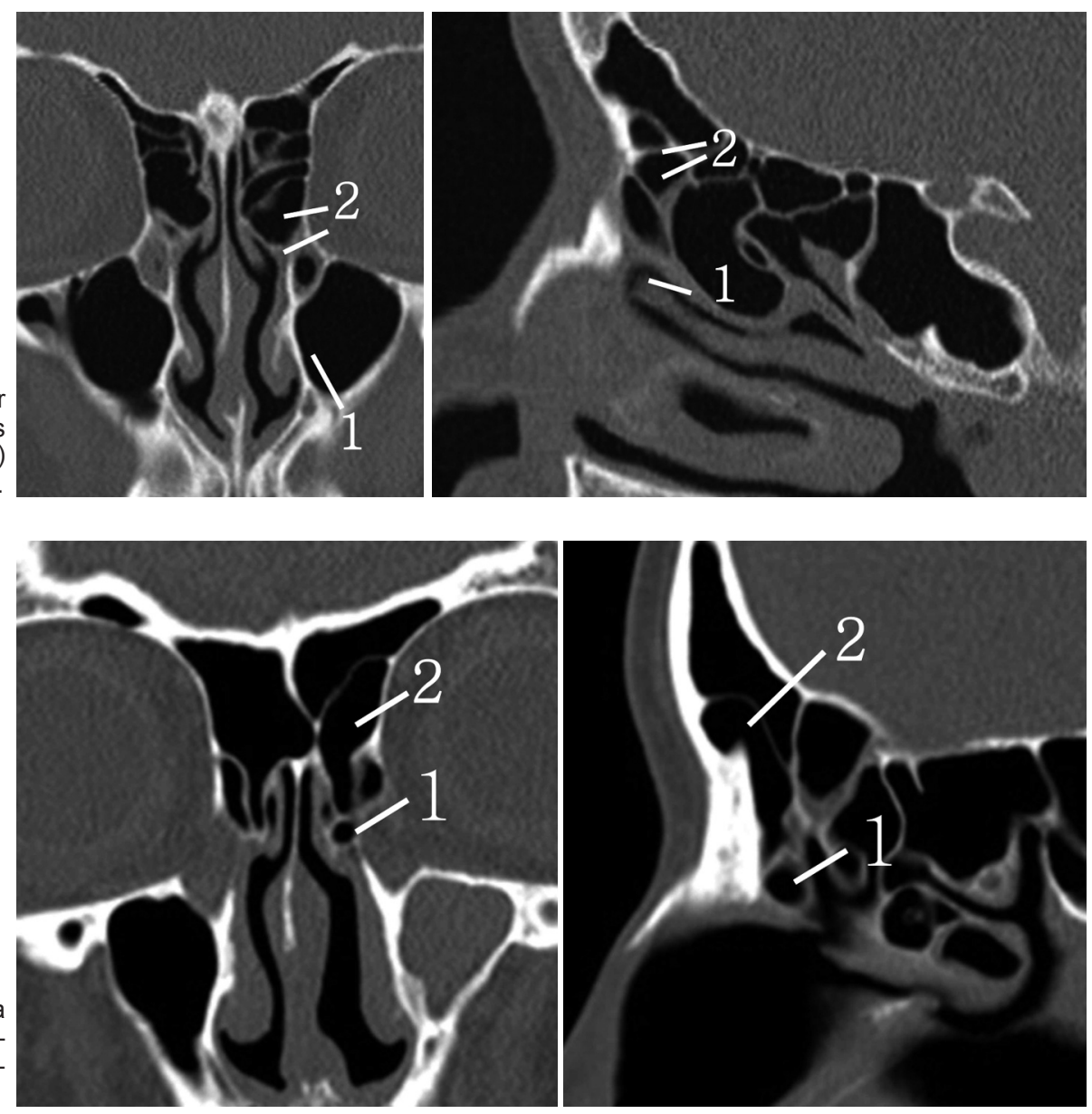

Fig. 3. The type III frontal cell (2) is a single large anterior ethmoid cell above the agger nasi cell (1) which extends far into true frontal sinus.

두동염이 있을 때 각각 $9.7 \%$ (3측), $12.9 \%$ (4측), $41.9 \%$ (13측)에 서 발견되었으며 전두동염이 없을 때는 각각 $37.0 \%(63$ 측), 12.3 $\%(21$ 측), $14.7 \%$ (25측)에서 발견되었다.

동간종격봉소는 전두동염이 있을 때 $6.4 \%$ (2측)로 환기되는 것이 관찰되었으며 전두동염이 없을 때는 $15.5 \%$ (15측)로 환기 되는 것이 관찰되었다. 말단와는 전두동염이 있을 때 $25.8 \%$ (8 측)에서 관찰되었으며 전두동염이 없을 때 $38.2 \%$ (65측)에서 
Fig. 4. The supraorbital ethmoidcell ${ }^{*}$ ) pneumatizes over the orbit (coronal image) and opens into lateral and posterior portion of the true frontal sinus (axial image).
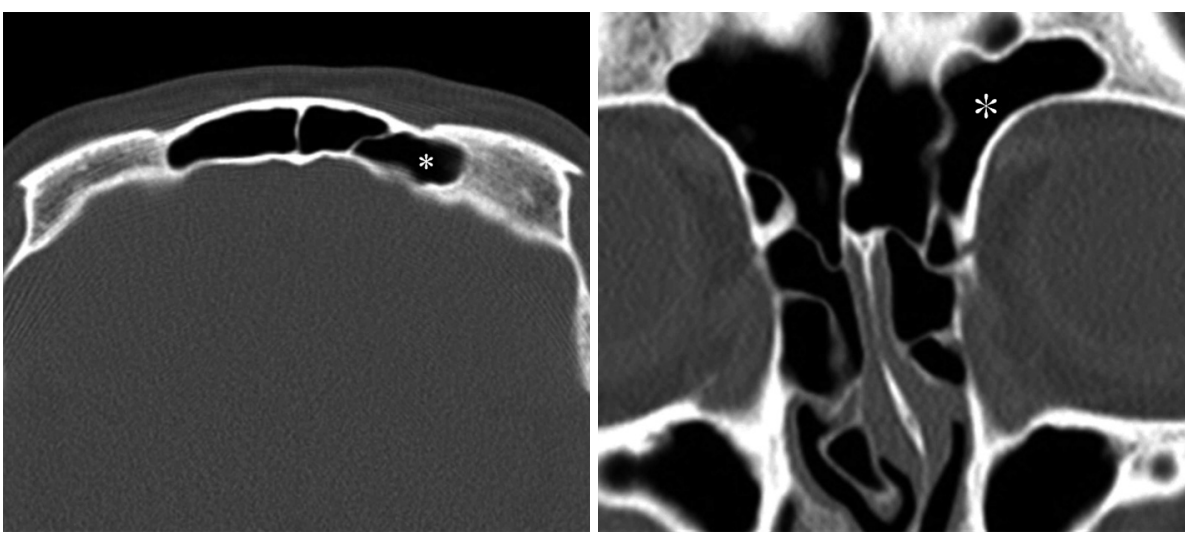

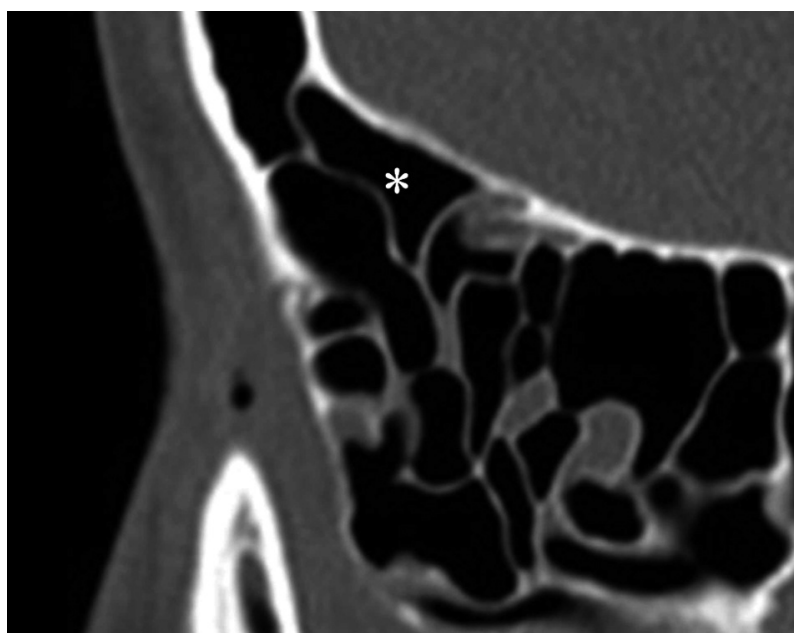

Fig. 5. The frontal bullar $\left(^{*}\right)$ pneumatized along the skull base into frontal sinus from posterior frontal recess as shown in sagittal CT images. It is located above ethmoid bulla.

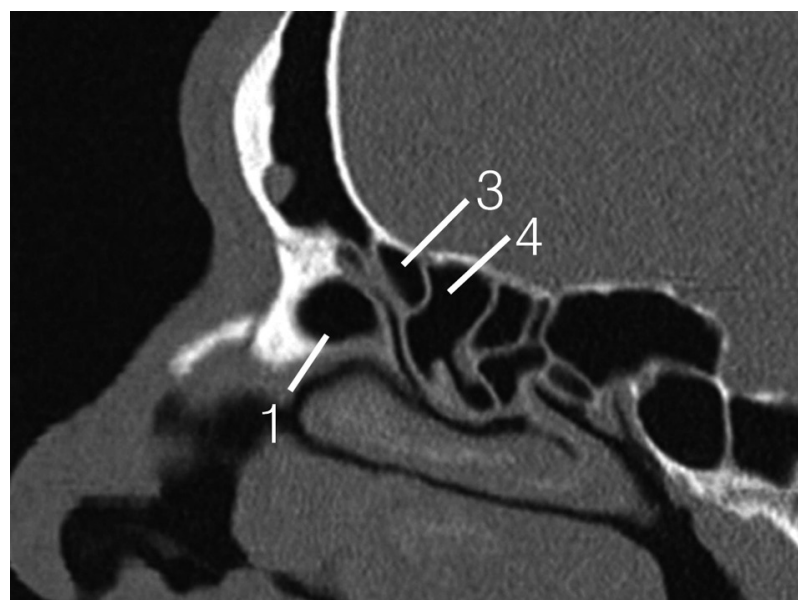

Fig. 6. The suprabullar cell (3) is seen above ethmoid bulla (4) in this sagittal image. The superior wall of suprabullar cell is anterior cranial skull base and anterior border does not extend into frontal sinus. Aggernasi cell (1) is also seen in this image.
Fig. 7. Interfrontal sinus septal cell $\left(^{*}\right)$ (A) and recessusterminalis $\left({ }^{*}\right)(B)$ are seen on coronal CT.

\section{발견되었다(Table 3).}

전두동 개구부 봉소들, 전두동 배출로의 최소거리 및 단면 적과 전두동염 발생의 연관성을 일변량 및 다변량 회귀분석하 였다. 전두사골포봉소는 일변량 $(p=0.001)$ 및 다변량 $(p=0.038)$ 회귀분석을 시행하였을 때 통계학적으로 유의성이 관찰되었다. 상사골포봉소는 회귀분석하였을 때 일변량 회귀분석 $(p=0.007)$ 으로는 통계적 유의성이 관찰되었으나, 다변량 회귀분석 $(p=$
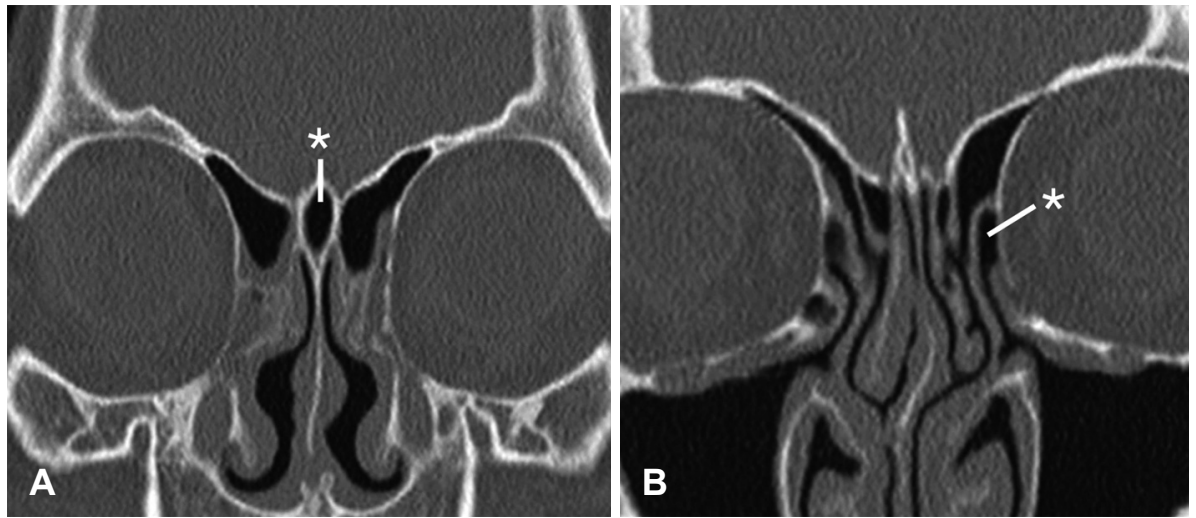

0.068)으로는 유의성을 보이지 않았다. 비제봉소, 제1형, 제2형, 제3형 전두봉소, 상안와봉소, 말단와는 일변량 및 다변량 회 귀분석에서 유의성이 관찰되지 않았다. 전두동 배출로의 단면적 은 일변량 회귀분석 $(p=0.013)$ 및 다변량 회귀분석 $(p=0.017)$ 에 서 전두동염과의 통계적 유의성이 관찰되었으나 전두동 배출 로의 최소거리는 통계적 유의성이 관찰되지 않았다(Table 3).

이상의 결과로 전두사골포봉소의 존재시 전두동염의 발생 
이 증가하였으며, 전두동 배출로의 최소면적이 좁을수록 전두 동염의 발생이 증가하였기에, 전두사골포봉소가 존재할 때 전 두동 배출로의 최소면적과의 관계에 대하여 알아보았다. 전두 사골포봉소가 존재할 경우 면적이 $79.908 \mathrm{~mm}^{2}$ 으로 존재하지

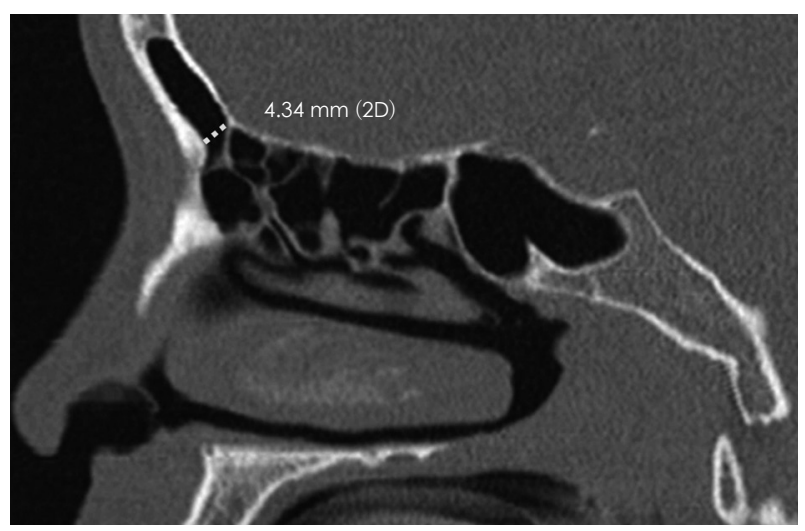

Fig. 8. The diameter of the nasofrontal isthmus was measured the distance between the most posterior projection of frontal beak to the junction of the posterior wall of the frontal sinus and the anterior ethmoid in sagittal reconstructed image.

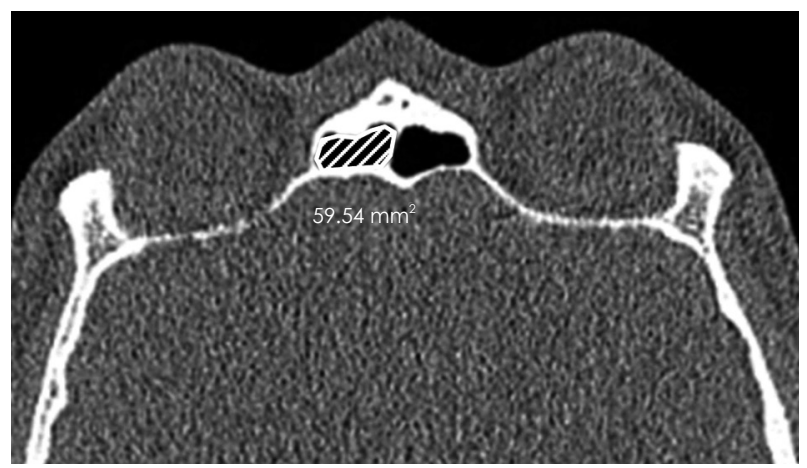

Fig. 9. Obliquely reconstructed axial image which demonstrate an example of a measuring the area of the nasofrontal isthmus. Nasofrontal isthmus is outlined to calculate the area by using Rapidia version 2.8 tools.
않을 경우의 $91.876 \mathrm{~mm}^{2}$ 으로 작았으나 two-samples t-test 를 사용하여 분석한 결과 통계학적으로 유의한 결과 $(p=0.125)$ 를 보이지 않았다.

\section{고 찰}

전두와봉소의 발현율은 비제봉소, 전두봉소 2형 및 3형, 상 사골포봉소, 전두사골포봉소는 Lee 등히이 보고한 서양인들 과는 차이가 있었으며, Cho 등이이 보고한 한국인들과 발현율 이 더 비슷하였다. 전두봉소 1 형은 $31.8 \%$ 에서 발견되었으며 Cho 등 ${ }^{8)}$ 이 보고한 $22.8 \%$ 에 비해, Lee 등 ${ }^{6}$ 이 보고한 $35.4 \%$ 에 보다 근접하였다. Cho 등이이 연구한 한국인, Lien 등리 이 연구 한 대만인, $\operatorname{Han}$ 등'이 연구한 중국인과 Lee 등히이 보고한 서 양인의 경우를 비교하였을 때 전두봉소 1 형과 상안와봉소가 동양인에 비하여 발현율이 높았다. 이러한 결과는 서양인이 동 양인에 비해 더 돌출된 상안와 및 미간을 가지는데 이러한 외 견상의 결과와 일치할 것으로 생각된다. ${ }^{8)}$ 본 연구에서 상안와 봉소는 앞선 동양인의 경우와 비슷한 결과를 보였으나, 전두봉 소 1형의 발현율은 보다 높아 동양인의 경우와 차이가 있다. Cho 등 ${ }^{8)}$ 이 연구한 전산화단층촬영의 경우 $1.25 \mathrm{~mm}$ 로 촬영 하여 본 연구의 $0.75 \mathrm{~mm}$ 보다 넓은 간격으로 측정하였기에 본 연구에서는 보다 미세한 봉소들을 발견하였을 가능성이 있다 (Table 2).

부비동염은 부비동 자연공의 개방, 정상적인 점액섬모기능, 정상적인 분비물의 생성이 중요한 인자로 작용하는데 이러한 요인들이 손상을 받을 때 발생하게 된다. 전두동의 경우 전두 동 배액로의 구조물이 다른 부비동에 비해 복잡하여 전두와 봉소 및 전두동염과의 관계에 대한 연구가 활발히 진행되고 있 다. 비제봉소의 경우 Bradley와 Kountakis ${ }^{10)}$ 는 내시경적 부비

Table 2. Comparison of percentage of various frontal recess cells identified on computed tomographic images

\begin{tabular}{|c|c|c|c|c|c|}
\hline Cell Types & $\begin{array}{c}2011 \text {; Korean; } \\
201 \text { sides, No. (\%) }\end{array}$ & $\begin{array}{c}\text { Lien et al., }{ }^{2)} \\
\text { 2010; Taiwanese, } \\
365 \text { sides, No. (\%) }\end{array}$ & $\begin{array}{c}\text { Han et al.," } \\
\text { 2008; Chinese, } \\
404 \text { sides, No. (\%) }\end{array}$ & $\begin{array}{c}\text { Cho et al.., } \\
\text { 2006; Korean, } \\
114 \text { sides, No. (\%) }\end{array}$ & $\begin{array}{c}\text { Lee et al.., } \\
2004 \text {; Caucasian, } \\
82 \text { sides, No. }(\%)^{*}\end{array}$ \\
\hline ANC & $184(91.5)$ & $323(89.0)$ & $380(94.1)$ & $107(94.0)$ & $71(86.6)$ \\
\hline FC 1 & $64(31.8)$ & $78(21.5)$ & $98(24.4)$ & $26(22.8)$ & $29(35.4)$ \\
\hline FC 2 & $28(13.9)$ & $38(10.5)$ & $28(7.0)$ & $16(14.0)$ & $17(20.7)$ \\
\hline FC 3 & $16(8.0)$ & $28(7.7)$ & $33(8.2)$ & $9(7.9)$ & $7(8.5)$ \\
\hline FC 4 & 0 & 0 & 0 & 0 & 0 \\
\hline SBC & $67(33.3)$ & $142(39.1)$ & $148(36.6)$ & $45(39.5)$ & $9(11.0)$ \\
\hline SOEC & $25(12.4)$ & $28(7.7)$ & $22(5.4)$ & $3(2.6)$ & $53(64.6)$ \\
\hline $\mathrm{FBC}$ & $38(18.9)$ & $23(6.3)$ & $36(9.0)$ & $15(14.0)$ & $5(6.1)$ \\
\hline RT & $73(36.3)$ & $159(43.8)$ & $360(89.1)$ & $76(66.7)$ & $25(22.0)$ \\
\hline IFSSC & $17(8.5)$ & $35(9.6)$ & $25(12.4)$ & $10(8.8)$ & $6(7.3)$ \\
\hline
\end{tabular}

* of the 100 sides analyzed by Lee et al. in 2004. 82 sides were Caucasian. ANC: aggernasi cell, FC 1 to 4: frontal cell types 1 to 4 , SBC: suprabullar cell, SOEC: supraorbital ethmoid cell, FBC: frontal bullar cell, RT: recessusterminalis, IFSSC: interfrontal sinus septal cell 
Frontal Recess Cells and Development of Frontal Sinusitis I Jung JH, et al.

Table 3. Statistical analysis of the effect of frontal recess cells on the development of frontal sinusitis

\begin{tabular}{|c|c|c|c|c|c|c|c|c|}
\hline \multirow{2}{*}{ Variable } & \multirow{2}{*}{$\begin{array}{l}\text { Frontal sinusitis, } \\
31 \text { sides, No. (\%) }\end{array}$} & \multirow{2}{*}{$\begin{array}{l}\text { No frontal sinusitis, } \\
170 \text { sides, No. (\%) }\end{array}$} & \multicolumn{3}{|c|}{ Univariate logistic regression } & \multicolumn{3}{|c|}{ Multivariate logistic regression } \\
\hline & & & OR & $95 \% \mathrm{Cl}$ & p-value & OR & $95 \% \mathrm{Cl}$ & p-value \\
\hline ANC & $28(90.3)$ & $156(91.8)$ & 0.838 & $(0.226-3.105)$ & 0.791 & 1.092 & $(0.234-5.094)$ & 0.910 \\
\hline FC 1 & $12(38.7)$ & $52(30.6)$ & 1.433 & $(0.649-3.167)$ & 0.374 & 1.207 & $(0.449-3.245)$ & 0.709 \\
\hline FC 2 & $2(6.5)$ & $26(15.3)$ & 0.382 & $(0.086-1.699)$ & 0.206 & 0.484 & $(0.091-2.564)$ & 0.393 \\
\hline $\mathrm{FC} 3$ & $3(9.7)$ & $13(7.6)$ & 1.294 & $(0.346-4.835)$ & 0.702 & 0.845 & $(0.158-4.522)$ & 0.844 \\
\hline SOEC & $4(12.9)$ & $21(12.3)$ & 1.051 & $(0.334-3.304)$ & 0.932 & 0.725 & $(0.202-2.597)$ & 0.621 \\
\hline FBC & $13(41.9)$ & $25(14.7)$ & 4.189 & $(1.826-9.608)$ & 0.001 & 2.786 & $(1.061-7.317)$ & 0.038 \\
\hline$S B C$ & $3(9.7)$ & $63(37.0)$ & 0.182 & $(0.053-0.623)$ & 0.007 & 0.287 & $(0.075-1.097)$ & 0.068 \\
\hline IFSSC & $2(6.4)$ & $15(5.5)$ & 0.480 & $(0.137-1.681)$ & 0.251 & 0.478 & $(0.122-1.872)$ & 0.289 \\
\hline RT & $8(25.8)$ & $65(38.2)$ & 0.562 & $(0.237-1.330)$ & 0.190 & 0.488 & $(0.192-1.243)$ & 0.133 \\
\hline $\mathrm{NID}(\mathrm{mm})$ & $5.85 \pm 2.40$ & $5.71 \pm 2.02$ & 1.031 & $(0.859-1.237)$ & 0.745 & 1.225 & $(0.971-1.547)$ & 0.087 \\
\hline $\mathrm{ANI}\left(\mathrm{mm}^{2}\right)$ & $71.57 \pm 32.17$ & $92.90 \pm 44.25$ & 0.985 & $(0.973-0.997)$ & 0.013 & 0.980 & $(0.965-0.996)$ & 0.017 \\
\hline
\end{tabular}

ANC: aggernasi cell, FC 1 to 4: frontal cell types 1 to 4, SOEC: supraorbital ethmoid cell, FBC: frontal bullar cell, SBC: suprabullar cell, IFSSC: interfrontal sinus septal cell, RT: recessusterminalis, NID: nasofrontalisthumus diameter, ANI: area of nasofrontal isthmus, Cl: confidence interval, OR: odds ratio

동 수술 후 재발한 전두동염은 비제봉소의 점막병변 존재유무 와 유의한 상관관계가 있다고 하였고, Lee와 Lee느는 비제봉 소의 존재와 전두동염 간에 유의한 상관관계가 있다고 보고 하였다. 이에 반해 DelGaudio 등근 117 명을 대상으로 연구하 였을 때 비제봉소 및 전두봉소는 전두동염의 발생과 연관이 없다고 보고하였으며, $\mathrm{Kim}$ 등1ㅡㄴ 슨 113 명의 어린이들을 대상으 로 연구하였을 때 비제봉소는 비부비동염의 발생과 관계가 없 다고 보고하였다. 이외 보다 많은 수의 연구결과들이 비제봉소 와 전두동염 간에는 유의한 관련이 없다고 보고하였다. ${ }^{2,12}$ 본 연 구에서는 부비동염이 존재할 경우 비제봉소의 발현율이 $93.9 \%$ 로 부비동염이 존재하지 않을 경우의 $91.8 \%$ 로 발현율은 높았 으나 통계학적 유의성은 관찰되지 않았다. 이러한 결과로 비제 봉소의 존재 유무 및 크기는 전두동염에 큰 영향을 미치지 않 을 것으로 판단된다.

전두봉소의 경우 DelGaudio 등근 117 명의 환자를 대상으 로 분석하여 전두봉소와 전두동염 간에는 유의한 상관관계가 없는 것으로 보고하였으며, Lien 등은 192 명의 대만인 환자 를 대상으로 분석하여 전두봉소와 전두동염 간에는 유의한 상 관관계가 없다고 보고하였다. Woo 등은 317명의 환자를 대 상을 연구하였을 때 제4형 전두봉소는 전두동염과 유의한 연 관성을 보였다고 보고하였다. Lee와 Lee ${ }^{5)}$ 는 한국인 225 명의 환자를 대상으로 분석하여 제4형 전두봉소는 전두동염과 유 의한 연관성이 있다고 보고하였으며, Meyer 등흐는 768 명을 분석하여 제 3 형 및 제4형 전두봉소는 전두동 점막의 비후가 통계적으로 높은 빈도로 관찰된다고 보고하였다. 이렇게 전두 봉소와 전두동염의 관계에 대해서도 상반된 결과로 보고되고 있 으며, 제 3 형 및 제 4 형에서만 유의한 보고가 있었다. 본 연구에 서는 부비동염이 동반되었을 때 1형, 2형, 3형의 전두봉소 발 현비율은 각각 $38.7 \%, 6.5 \%, 9.7 \%$ 였다. 부비동염이 동반되지
않았을 경우에는 비율이 각각 $30.6 \%, 15.3 \%, 7.6 \%$ 였으며 제 4 형 전두봉소는 관찰할 수 없었다. 본 연구에서는 3형까지의 전 두봉소는 전두동염의 발생과 의미있는 상관관계를 보이지 않 았다(Table 3). 4형 전두봉소는 본 연구에서 나타나지 않았으 며 Lien 등릐 읜구에서도 관찰되지 않았다. 제 3 형 전두봉소 는 총 16 명의 환자에서 관찰할 수 있었으나 연구대상이 17 측 으로 개체수가 적어 의미있는 분석이 되지 않았을 수 있으며, 좀 더 많은 대상을 이용하여 전두동의 유출로를 막고 있는 정 도들에 대한 연구가 필요할 것으로 생각된다.

전두와봉소의 분류는 Lee 등에 에 의해 발전되었으며 개구 부의 후방에 위치한 상안와봉소, 전두사골포봉소, 상사골포봉 소에 대해서도 명확히 정의하고 있다. ${ }^{8}$ 전두동 수술시에는 앞쪽 으로 돌출된 후방군봉소들에 의해서도 어려움을 겪을 수 있 으며 전두동염의 발생에도 영향을 미칠 수 있으나 후방 전두와 봉소에 관하여는 연구가 활발하지 못한 상태이다. Lien 등은 192 명의 대만 환자를 대상으로 연구하여, 후방 전두와봉소가 전두동 배출로의 길이를 짧게 하여 전두동염의 발생이 증가 할 수 있다고 보고하였으며, Zhang 등 $\left.{ }^{14}\right)$ 은 11 명의 부비동염 환 자를 대상으로 상안와봉소가 부비동염의 발생에 영향을 줄 수 있다고 보고하였다. 본 연구에서는 부비동염이 존재할 경 우 전두사골포봉소의 비율이 $41.9 \%$ 로 부비동염이 존재하지 않 을 경우의 $14.7 \%$ 보다 높게 관찰되었으며, 일변량 $(p=0.001)$ 및 다변량 $(p=0.038)$ 회귀분석을 시행하였을 때 통계학적으로 유 의성이 관찰되었으며, 상사골포봉소는 일변량 $(p=0.007)$ 회귀 분석에서만 유의한 관계를 보였다. 상안와봉소는 유의한 관계 를 나타내지 않았다(Table 3). 이러한 결과는 전두사골포봉소 의 경우 봉소의 일부분이 전두동으로 돌출되게 되어 전두동의 자연공이 좁아져 전두동염의 발생빈도가 증가할 것으로 생각 된다. 이전 연구에는 전방군의 봉소에 대한 연구는 많은 데에 
비해 후방군 전두동 개구부 봉소에 대한 연구는 많지 않아 이 에 대한 연구도 필요할 것으로 생각한다.

DelGaudio 등 ${ }^{7)}$ 이 전두동 배출로의 최소거리 및 최소면적을 측정하여 전두동염과의 관계를 분석하였으나 통계학적 유의 성이 관찰되지 않아, 전두동염의 원인인자에 있어 전두동 배출 로의 크기가 가장 중요한 인자는 아니라고 보고하였다. 본 연 구에서는 동일한 방법으로 최소거리 및 최소면적을 측정하여 분석하였을 때 최소거리는 통계학적 유의성을 나타나지는 않 았으나 면적에 있어서는 일변량 $(p=0.013)$ 및 다변량 $(p=0.017)$ 회귀분석에서 통계학적 유의성을 보였다(Table 3). 전두동 배 출로의 단면이 항상 원형을 이루지 않으며 타원형 혹은 아령 모양으로 단면을 이루는 경우가 많았기 때문에 최소거리만으 로는 배출로의 크기를 알기 어려우며 단면적으로 크기를 분석 해야 할 것이다.

전두사골포봉소의 전두동 배출로의 돌출로 배출로의 면적 을 작게 하여 배액에 영향을 미칠 수 있을 것으로 생각되어, 전 두사골포봉소의 존재와 전두동 배출로의 면적의 상관관계를 two-samples t-test를 사용하여 분석하였으나 유의한 결과 $(p=0.125)$ 를 보이지 않았다. 이에 대해 전두사골포봉소의 존 재가 생리학적으로 점액의 배출에 영향을 준 것을 생각해 볼 수 있으며, 해부학적인 원인에 대해서는 개체수가 적어 유의한 결과에 도달하지 못하였을 가능성을 고려해 볼 수 있었다.

본 연구에서는 전두동 개구부 봉소가 전두동염의 발생에 영 향을 미칠 수 있는지에 대하여 연구하였다. 앞선 대상자 중 광 범위한 비용종으로 배출로에 영향을 미칠 수 있는 환자들은 제외하였으나, 사골동 혹은 상악동의 부비동염 등 전두동염에 영향을 줄 수 있는 다른 인자를 모두 제외하지 못하였다. 단독 전두동염 환자만을 대상으로는 개체수가 너무 적었다. 전두동 개구부 봉소의 영향에 대하여 자세히 알기 위해서는 여러 의 료기관들의 단합으로 단독 전두동염 환자만을 대상으로 연구 가 진행되면 더욱 의미있는 결과를 보일 수 있을 것으로 생각 한다.

전두동염의 원인으로는 점액섬모기능의 이상, 분비물 생성 의 이상, 혹은 점막의 염증인자일 수 있으며 해부학적 부비동 자연공의 폐쇄 또한 중요한 인자이다. 후방군 전두동 개구부 봉 소 또한 전두동 배출로의 구조를 좁게 하여 전두동염의 원인 이 될 수 있으며 전두동염의 원인으로 배출로의 해부학적 구 조 또한 간과되어서는 안된다. 이전 연구에서는 주로 비제봉
소 같은 전방군 전두동 개구부 봉소에 대한 연구는 많이 보고 되었으나, 후방군 전두동 개구부 봉소에 대하여는 많은 연구 가 있지 않았다. 본 연구는 후방군 전두동 개구부 봉소도 또 한 전두동염의 원인이 될 수 있을 것으로 제시한다. 임상적으 로, 후방군 전두동 개구부 봉소 또한 수술시 제거가 되어야 하 며 남겨져 있을 경우 전두동염의 재발에 영향을 미칠 수 있을 것으로 생각된다.

\section{REFERENCES}

1) Woo HJ, Ye SB, Bae CH, Song SY, Kim YD. Anatomic variations of the frontal recess and frontal sinusitis: computed tomographic analysis. J Rhinol 2009;16(1):20-5.

2) Lien CF, Weng HH, Chang YC, Lin YC, Wang WH. Computed tomographic analysis of frontal recess anatomy and its effect on the development of frontal sinusitis. Laryngoscope 2010;120(12):2521-7.

3) Shin SH, Lee HS, Park JY. Computed tomographic findings of frontal sinusitis. Korean J Otolaryngol-Head Neck Surg 1997;40(2): 169-74.

4) Min YG, Choo MJ, Rhee CS, Jin HR, Shin JS, Cho YS. CT analysis of the paranasal sinuses in symptomatic and asymptomatic groups. Korean J Otolaryngol-Head Neck Surg 1993;36(5):916-25.

5) Lee JH, Lee SO. Frontal sinusitis related to anatomic variations. Korean J Otolaryngol-Head Neck Surg 2004;47(8):751-5.

6) Lee WT, Kuhn FA, Citardi MJ. 3D computed tomographic analysis of frontal recess anatomy in patients without frontal sinusitis. Otolaryngol Head Neck Surg 2004;131(3):164-73.

7) DelGaudio JM, Hudgins PA, Venkatraman G, Beningfield A. Multiplanar computed tomographic analysis of frontal recess cells: effect on frontal isthmus size and frontal sinusitis. Arch Otolaryngol Head Neck Surg 2005;131(3):230-5.

8) Cho JH, Citardi MJ, Lee WT, Sautter NB, Lee HM, Yoon JH, et al. Comparison of frontal pneumatization patterns between Koreans and Caucasians. Otolaryngol Head Neck Surg 2006;135(5):780-6.

9) Han D, Zhang L, Ge W, Tao J, Xian J, Zhou B. Multiplanar computed tomographic analysis of the frontal recess region in Chinese subjects without frontal sinus disease symptoms. ORL J Otorhinolaryngol Relat Spec 2008;70(2):104-12.

10) Bradley DT, Kountakis SE. The role of agger nasi air cells in patients requiring revision endoscopic frontal sinus surgery. Otolaryngol Head Neck Surg 2004;131(4):525-7.

11) Kim HJ, Jung Cho M, Lee JW, Tae Kim Y, Kahng H, Sung Kim H, et al. The relationship between anatomic variations of paranasal sinuses and chronic sinusitis in children. Acta Otolaryngol 2006;126 (10):1067-72.

12) Al-Qudah M. The relationship between anatomical variations of the sino-nasal region and chronic sinusitis extension in children. Int $\mathrm{J}$ Pediatr Otorhinolaryngol 2008;72(6):817-21.

13) Meyer TK, Kocak M, Smith MM, Smith TL. Coronal computed tomography analysis of frontal cells. Am J Rhinol 2003;17(3):163-8.

14) Zhang L, Han D, Ge W, Tao J, Wang X, Li Y, et al. Computed tomographic and endoscopic analysis of supraorbital ethmoid cells. Otolaryngol Head Neck Surg 2007;137(4):562-8. 